\title{
Women's Vulnerability in Performing Reproductive Functions in the Covid-19 Pandemic
}

\author{
Usfiyatul Marfu'ah ${ }^{1}$, Siti Rofi'ah ${ }^{2}$, Najahan Musyafak ${ }^{3}$ \\ \{usfiyatulmarfuah@walisongo.ac.id ${ }^{1}$, siti_rofiah@walisongo.ac.id ${ }^{2}$, \\ najahan_musyafak@walisongo.ac.id ${ }^{3}$ \} \\ Walisongo State Islamic University, Semarang, Indonesia
}

\begin{abstract}
COVID-19 has resulted biological, psychological, and economic vulnerability on women's reproduction. During the pandemic, women undergoing reproductive functions can not afford sufficient nutritional needs. At the same time, they also do not receive adequate accommodation support during self-isolation. This study aims to complement the existing studies by focusing on three things; First, what the form of vulnerability of the female reproductive process during the pandemic is. Second, what factors cause the vulnerability of women's reproductive processes during the pandemic. Third, what the implications of the vulnerability of women's reproductive functions to reproductive health are. This study uses exploratory qualitative research based on primary and secondary data. Primary data were obtained through in-depth interviews with policy makers, survivors, health workers and COVID-19 volunteers in Semarang. Secondary data was obtained through statistical data from the Health Service, COVID-19 Task Force, BNPB, shelter houses, health centers and online news. The results of this study are not only able to objectively map the vulnerability of women during the reproductive period during a pandemic, but also provide information on the needs of women's reproductive groups during a pandemic. In addition, this study provides input for policy makers to carry out affirmative action in handling women undergoing the reproductive process during the COVID-19 pandemic.
\end{abstract}

Keywords: COVID-19 Pandemic; Women's Vulnerability; Reproductive Health

\section{Introduction}

COVID-19 has affected vulnerability of women who are experiencing reproductive function on biological, psychological, and economic dimensions. The policy of physical distancing and restrictions on social interaction resulted in the absence of friends to discuss and consult. Pregnant women are worried about their unborn baby being exposed to the corona virus. These worries caused him to stay at home and not interact socially. At the same time, the fear of going to a doctor or hospital for medical check-ups is another cause of stress for pregnant women. In addition to the three factors that cause stress in pregnant women, the increased workload at home due to the policy of working from home (WFH) is another trigger for psychological disorders (Oskovi-Kaplan et al. 2021; Power 2020).

So far, studies on the women vulnerability during a pandemic tended to focus on three areas of study. First, a study that makes the pregnancy issue during the COVID-19 period a 
central theme for women undergoing the reproductive process (Kayem et al. 2020; Pope et al. 2021; Rotshenker-Olshinka et al. 2021). Second, research that focuses on the analysis of women's mental health (Gómez-Salgado et al. 2020; Thibaut and van Wijngaarden-Cremers 2020). Third, articles that discuss the burden of women's lives and jobs are affected by the COVID-19 pandemic (Asriani et al. 2021; Fabrizio, Malta, and Tavares 2020; McLaren et al. 2020; Sarker 2021; Sulaeman and Salsabila 2020). As pointed out by Asriani et al. (2021) that the COVID-19 pandemic has added to the daily workload for women due to the working from home (WFH) policy. From these three trends, it appears that women's reproductive problems during the corona virus outbreak were neglected.

Women's vulnerability is understood as a condition that causes women's inability to face the threat of disasters they face (BNPB, 2012). Vulnerability is an aspects set of an individual or group related to their abilit level to respond to situations and to greater or lesser access to adequate resources. (Goes et al. 2020). Factors influencing women's vulnerability include low education, limited access to resources, economic conditions and cultural aspects (Hamidazada, Cruz, and Yokomatsu 2019), high anxiety aspect (Macauley, 2018), and decreased physical and mental health (Abdullah 2020; Gunadi et al. 2020; Pope et al. 2021; Preis et al. 2020; Rotshenker-Olshinka et al. 2021). Thus, women's vulnerability is not only seen from the physical aspect, but also from the mental, psychological and economic aspects.

Reproductive health is defined as a condition or state of complete physical, mental and social health, free from disease or disability related to reproductive systems, functions and processes in men and women. (Akbar dkk, 2021; Hasanah 2017). Reproductive health cannot be realized optimally due to several factors: poverty, education, health, violence, conflict, disaster, economy, policy, environment and discrimination. (Purkayastha, 2020; Mulyani, 2020; (Ernawati 2018; Hamidazada et al. 2019). This phenomenon shows the importance of understanding reproductive health and the influential factors.

This study aims to complement previous studies that did not pay attention to the issue of women undergoing the reproductive process during the COVID-19 pandemic. This study focuses carefully on three things; First, what the form of vulnerability of the female reproductive process during the pandemic is. Second, what factors cause the vulnerability of women's reproductive processes during the pandemic. Third, what the implications of the vulnerability of women's reproductive functions to reproductive health are. The answers to these three questions will be described sequentially in this paper.

This study uses exploratory qualitative research based on primary and secondary data. Primary data were obtained through in-depth interviews with informants including the Head of the Semarang Health Office as policy makers, health workers and COVID-19 volunteers in Semarang, and five pregnant women. Meanwhile, secondary data was obtained through online document searches in the form of statistical data from the Health Service, hospitals, COVID19 Task Force, BNPB, and COVID-19 shelters. Data analysis was carried out in two forms. First, data processing follows the stages of Huberman 2000). These stages start from reduction, data display, and data verification for the inference process. Second, the analysis used follows an interpretation technique starting from the "restatement" of the data found. Restoration is carried out on data that has been obtained through online searches. Description is a presentation of data classified from three types of vulnerabilities: biological, psychological and economic. Interpretation is carried out to reveal forms of vulnerability, causal factors and implications of vulnerability to women's reproductive health. 


\section{Results and Discussion}

\subsection{Results}

\subsubsection{Biological Vulnerability}

The biological vulnerabilities experienced by women in the reproductive process during the COVID-19 pandemic can be proven in three forms. First, the healing process after giving birth (postpartum) takes longer. The process of giving birth either by cesarean or vaginal has resulted in injury to the female organs. These injuries make women unable to meet their daily needs to prepare food, to take a bath, urinate, defecate, and take care of their babies. As a result, women need another's help to fulfill these needs for the wound healing process. With the physical distancing policy during the COVID-19 pandemic, the presence of the family to help with personal needs is limited according to the health protocol. This fact was revealed by the informant:

"...the absence of moral support and technical assistance when the baby cries. After the surgery and the anesthetic hasn't gone away, I need help to calm the baby down. Even though there are health workers, their presence cannot be continuously 24 hours a day." (Informant 3 )

Second, it is easy to get viruses. The women vulnerability to viruses is caused by internal and external factors. Women who are pregnant and giving birth have low immunity. They are fatigue by changes in rest periods and the additional responsibility of taking care of the baby. A weak immune system makes women vulnerable to the entry of viruses into the body. Meanwhile, the external factor is the compliance lack of the most visitors on hospital and health center to health protocols. They do not wear masks and wash their hands when visiting, even though there are regulations and warnings from officers. This condition is as described by the informant:

"...I felt uncomfortable because in some hospitals and health centers the health protocol was still a formality. Some visitors wore masks and some didn't. ...those who do not wear masks were usually only reprimanded by officers" (Informant 1, 2021)

Third, the potential for experiencing mastitis opens. Mastitis is an infection that occurs in the breast tissue and causes pain. This situation is caused by the blockage of the milk flow caused by the entry of bacteria into the breast ducts. Mastitis experienced by women during the COVID-19 pandemic was triggered by the stress of breastfeeding mothers. Informant 1 said that she was able to produce milk for her baby after one month of giving birth. To meet milk needs, babies are given formula milk (Informant 1, 2021).

The three evidences show that women undergoing the reproductive process experience biological vulnerabilities. This is not only caused by the long recovery time after giving birth, but also due to weak immunity, cessation of milk flow and a greater potential for death.

\subsubsection{Psychological Vulnerability}

The psychological vulnerability of women undergoing reproductive functions during the COVID-19 pandemic can be mapped into three forms: anxiety in pregnant women, postpartum blues and rapid fatigue. Pregnant women experience anxiety. This anxiety is caused by the assumption that health care facilities are actually not safe for themselves and their babies because they are in same places for checking and treating COVID-19 patients. Uncertainty about environmental conditions causes feelings of worry from time to time. Informant 2 stated: 
“...This second pregnancy is indeed different from the first pregnancy, I used to routinely check for pregnancy at the midwife or health center, but because of the pandemic I was afraid of getting infected, so I reduced the checks. When I checked I also often felt uncomfortable what they said, such as blaming my pregnancy, they said "you have already known the pandemic, why you are still pregnant." (Informant 2, 2021)

After giving birth, mothers experience postpartum blues. It is feelings of discomfort, fear and irritation with the situation. Discomfort Feelings arise because of restrictions on access to the baby. The treatment of childbirth imposed by the hospital is not well informed. This condition causes feelings of irritability and irritation towards the situation. This phenomenon was experienced and expressed by informant 3 :

“....after giving birth, the husband should give adzan to the baby, but because of the health protocol, the husband cannot hold the baby. I feel sad... when the baby cries, the husband should help calm him down, but instead the midwife takes care of him and hands him over to me..." (Informant 3, 2021)

Feelings of anxiety also continue when the mother returns home with her baby. The anxiety arises when neighbors and relatives visit the baby, while they do not comply with health protocols. She is worried that her baby will catch the corona virus. Informant 2 stated:

"At home, I felt anxious when the neighbors visited and held my baby, because they didn't wear masks" (Informant 2, 2021)

The third form of psychological vulnerability is feeling tired quickly. Women's fatigue is caused by excessive housework and night shifts due to WFH regulations during the COVID19 pandemic. The work from home (WFH) policy implemented by the government creates unclear working hours and workloads affecting time for rest. As explained by Informant 1 that shifting working hours to evenings causes changes in the time to take care of children and complete homework:

"Working hours are moved at night, finally those who have toddlers work erratically, when the children are asleep, they can only join the meeting" (informant 1, 2021)

The three vulnerability factors including anxiety in pregnant women, postpartum blues and feeling tired quickly are evidence of the COVID-19 influence on the psychology of women undergoing the reproductive process.

\subsubsection{Economic Vulnerability}

COVID-19 has posed not only biological and psychological vulnerabilities in women, but also economic vulnerabilities. Economic vulnerability of women can be seen from two things; reduced income and increased health care costs. The decrease in income was caused by breaking labor relations due to the Community Activity Restriction (PPKM) policy and being exposed to the corona virus. Informant 1 stated "...The income of the family is decreasing while the life necessities are still constant and even tend to increase". In fact, when her husband was exposed to COVID-19, the source of income from the company was cut off plus the burden of self-isolation.

The next economic vulnerability is characterized by increasing health costs. During COVID-19, the need for medicine, vitamins, and tests has increased. The nearest free health facility from the residence that has been serving, such as the Posyandu, has been temporarily suspended during PPKM. To access the Health Center and Hospital requires a long distance. Informant 3 shows the reality:

"When we go to the health center, we have to do a SWAB test. If you want to give birth you are also required to have a SWAB test and pay...expenses also increase when your 
husband gets COVID-19, buy medicine by yourself, pay for a swab test by yourself too" (Informant 1, 2021). These two pieces of evidence show that reduced incomes and increased demand for medicines and vitamins during the COVID-19 pandemic have created economic vulnerability for women.

\subsection{Discussion}

\subsubsection{COVID-19 and Women's Biological Vulnerabilities}

Giving birth makes women have experience pain caused by vaginal wounds or caesarean section incisions. Sectio caesarea surgery has caused pain due to the disconnection of tissue continuity that stimulates the sensory area. In this situation, postpartum or postpartum women generally choose to reduce physical movement to avoid increasing pain and to prevent wound infection in abdominal wall surgery. As indicated by Mitayani (2009) that infection is the second most common cause of death after bleeding. This condition makes postpartum women unable to carry out daily living activities and neglects personal hygiene needs. Supporting of family and closest people is an important factor to get optimal care. The assistance of husbands or family members plays a very important role in not only the smooth delivery process but also reducing the incidence of childbirth complications (Ministry of Health, 2004; Asrinah, 2010).

The postpartum period makes women need postnatal care and health services immediately. The postpartum happens when blood comes out of the uterus after giving birth (Anggraeni, 2010; Heryani 2012 as quoted by Fatwiany, et al 2020). This period is a crucial time where the possibility of infection is more open (Sulistyawati, 2009). The occurrence of puerperal infection is caused by the wound factor in the birth canal which is a medium for the development of germs. Medically, an episiotomy incision or rupture of the perineum causes swelling of the surrounding tissue, the edges of the wound become red and the sutures are easily detached. With the opening of the wound, the condition becomes an ulcer and discharges pus (Sulistyawati, 2009). This phenomenon allows the occurrence of infection to be greater. This can be exacerbated by low body resistance after childbirth, poor care, poor hygiene, malnutrition, and fatigue (Hariani, 2020).

Another form of biological vulnerability is the risk of mastitis or breast inflammation during lactation. Clinical manifestations of mastitis include redness, breast swelling, fever or systemic infection. Mastitis is divided into two levels, severe and moderate or mild (Østerås, 2009). This desease is caused by the blockage of the milk ducts (Alasiry, 2013; Pratiwi, 2020). The process of forming breast milk occurs through two stages. The first, the process of forming is influenced by the hormone prolactin, the amount of which adjusts the intensity of breastfeeding. The second is the process of releasing breast milk which is influenced by the hormone oxytocin (Bobak, 2005 in Nurliawati, 2010). The production of the hormone oxytocin is strongly influenced by the mother's anxiety, stress, excessive worry and unhappiness (Sulastri, 2016).

\subsubsection{Psychological Vulnerability}

The COVID-19 pandemic has psychological resulted vulnerability for reproduction women. There are two forms of vulnerability, anxiety in pregnant women and postpartum blues in mother giving birth. Anxiety is a general feeling of fear, unpleasant, vague, often accompanied by autonomic symptoms such as headache, palpitations, mild gastric 
disturbances or sweating. Women have the potential feeling of excessive anxiety due to sociological factor (Kuriake, 2021). As indicated by Macauley et al (2018), female was a significant predictor of all anxiety measures with a ratio of $51 \%$ women and $37.5 \%$ men. In addition, UN Women found that the percentage of women whose mental health was affected by the spread of COVID-19 was higher (57\%) than men (48\%) (UN Women, 2020).

The risk of anxiety becomes greater in pregnant women. During pregnancy, mothers experience many changes in physical, hormonal, psychological and emotional dimension. Emotionally, pregnant women experience sensitive feelings, changing moods, may behave irrationally and cry easily (Ministry of Health, 2006 in Sari, 2016). So, in a pandemic situation, the emotional sensitivity and anxiety of pregnant women will increase because they are faced with various fears such as falling sick and dying, contracting the virus, losing their livelihood, being expelled from work, being exiled by the community or being quarantined (Suphardiyan, 2020).

Furthermore, this anxiety can encourage the occurrence of postpartum blues. Postpartum blues is a psychological and physical syndrome experienced by women on the seven days to the first 14 days after giving birth. The experience of syndromes such as serious mood disorders can cause postpartum depression symptoms such as sadness, loneliness, crying, fatigue to sleep disturbances (Handayani and Purwati, 2021). This phenomenon can incrase when the mother feels lost support, transition to social roles, an uncomfortable home environment, anad the declining income (Suphardiyan, 2020). As a result, women feel tired of the mind and physically more than usual. The more anxious and tired the mother feels, the more the body will fail to produce antibodies to fight the virus, which makes the mother more vulnerable. This is evidence that the COVID-19 pandemic increases the vulnerability of women undergoing reproductive function.

\subsubsection{The Economic Vulnerability of Women During the Pandemic}

Economic vulnerability for women during the COVID-19 pandemic is characterized by declining income and increasing health costs. Decreasing of income was triggered by the government policy on a large-scale social restriction (PSBB). The policy changes the socioeconomic activities on public sectors such as limitation on opening hours for shopping centers and food stalls. As Melianna (2020) pointed out, the wave of layoffs occurred during the PSBB period in Indonesia. The percentage of layoffs of workers at the end of April 2020 was 15.6 percent. From the respondents studied, there are 31.0 percent of workers who claim that their income has decreased by less than 50 percent and 8.6 percent of workers whose income has decreased by more than 50 percent. Many women suddenly have to become the breadwinner of the family and lose their jobs. $36 \%$ of women informal workers had to reduce work time. They spent more time caring for and assisting children in learning at home (Aripurnami, 2021).

Another vulnerability emerges in increaing of health costs. These health costs include the purchase of drugs, medical devices and health care costs. This vulnerability increases when the shortage of drugs availability. Many factory closures their acticity due to quarantine, border closures, export bans, anad quarantine of countries. As the results, supply of raw materials and medicines decreased while the demand for medicines increased (Meliawati and Kholik, 2020). At the same time, the price of medicine during the pandemic is expensive. The price increase reached 10 times than usual. The high demand for drugs is used by some business actors to increase the selling price of drugs to the public (Firdaus and Sukarelawati, 2021). 
In addition to the scarcity of medicines and medical devices, inadequate hospital capacity has forced COVID-19 patients to self-isolate at home. Independent isolation without adequate equipment due to limited health care facilities and minimal medicines can increase the risk of death. LaporCovid data shows that from June to July 22, 2021, there were 2,313 Covid patients who died while undergoing self-isolation (Amalia, 2021). Several private hospitals offer isolation packages at hotels that have collaborated with hospitals. The high price of selfisolation offered by private hospitals is very unaffordable for them who experienced a decrease in income and lost their jobs due to layoffs during the pandemic. Thus, reproductive health cannot be realized optimally because as stated by that economic factors, poverty and weak policies will determine how reproductive health can be realized (Nurdiana, 2021; Purkayastha and Mulyani, 2020).

\section{Conclusion}

This study found that COVID-19 has worsened the situation of women who are undergoing reproductive function not only in the biological aspect, but also in the psychological and economic aspects. Woman's vulnerability is indicated by the length of the postnatal recovery period due to the absence of family support and good health services. At the same time, women are also worried that their baby will be infected by the corona virus. The situation is getting worse with decreasing family income and the inability to access vitamins and medicines due to high prices. These three things make women vulnerable in preparation, process, and post-natal care during the COVID-19 pandemic.

This paper has several limitations such as the number of informants, accessible research area, and the cases that are the focus of the discussion. The limited informants caused by restrictions on social interaction during the pandemic so that data exploration can only be done through online media. Meanwhile, the research area that is limited to one area causes the variety of cases revealed to be less diverse. On the other hand, outside of the biological, psychological, and economic aspects, it has not received fully attention. So, there are open space for further research to find out other aspects of the women vulnerability both in general and specifically for women who are undergoing reproductive functions during the pandemic.

\section{References}

[1] Abdullah, Irwan. 2020. "COVID-19: Threat and Fear in Indonesia." Psychological Trauma: Theory, Research, Practice, and Policy 12(5):488-90. doi: $10.1037 / \operatorname{tra0000878.~}$

[2] Asriani, Desintha Dwi, Dati Fatimah, Mida Mardhiyyah, and Aminatun Zubaedah. 2021. "The Changes in the Daily Activities Cycle of Women Informal Workers during the COVID-19 Pandemic: Vulnerability and Resilience." Sawwa: Jurnal Studi Gender 16(1):19-42. doi: 10.21580/sa.v16i1.7112.

[3] Asrinah. 2010. Asuhan Kebidanan Masa Persalinan. Yogyakarta: Graha Ilmu.

[4] Bapenas. n.d. "Laporan Perkembangan Pencapaian Tujuan Pembangunan Milenium Indonesia." 57-62.

[5] Emy, Ni Putu, Darma Yanti, I. Made, Arie Dharma, Putra Nugraha, Gede Adi Wisnawa, Ni Putu, Dian Agustina, and Arsita Diantari. 2020. GAMBARAN PENGETAHUAN MASYARAKAT TENTANG COVID-19 DAN PERILAKU 
MASYARAKAT DI MASA PANDEMI COVID-19.

[6] Ernawati, Hery. 2018. "Pengetahuan Kesehatan Reproduksi Remaja Di Daerah Pedesaan." Indonesian Journal for Health Sciences 2(1):58. doi: 10.24269/ijhs.v2i1.820.

[7] Fabrizio, Stefania, Vivian Malta, and Marina M. Tavares. 2020. "COVID-19: A Backward Step for Gender Equality." VOX, CEPR Policy Portal (Https://Voxeu.Org) (Figure 2):2-5.

[8] Gail, Stuart W. 2002. Buku Saku Keperawatan Jiwa. Jakarta: EGC.

[9] Goes, Emanuelle Freitas, Greice M. S. Menezes, Maria da Conceição C. Almeida, Thália Velho Barreto de Araújo, Sandra Valongueiro Alves, Maria Teresa Seabra Soares Britto E. Alves, and Estela M. L. Aquino. 2020. "Vulnerabilidade Racial e Barreiras Individuais de Mulheres Em Busca Do Primeiro Atendimento Pós-Aborto." Cadernos de Saude Publica 36Suppl 1(Suppl 1):e00189618. doi: 10.1590/0102311 X00189618.

[10] Gómez-Salgado, Juan, Montserrat Andrés-Villas, Sara Domínguez-Salas, Diego DíazMilanés, and Carlos Ruiz-Frutos. 2020. "Related Health Factors of Psychological Distress during the COVID-19 Pandemic in Spain." International Journal of Environmental Research and Public Health 17(11). doi: 10.3390/ijerph17113947.

[11] Gunadi, Yofizal Idham, Vincentia Meta Widya Paramita, Aditya Rifqi Fauzi, Andi Dwihantoro, and Akhmad Makhmudi. 2020. "The Impact of COVID-19 Pandemic on Pediatric Surgery Practice: A Cross-Sectional Study." Annals of Medicine and Surgery 59(September):96-100. doi: 10.1016/j.amsu.2020.09.020.

[12] Hamidazada, Marina, Ana Maria Cruz, and Muneta Yokomatsu. 2019. "Vulnerability Factors of Afghan Rural Women to Disasters." International Journal of Disaster Risk Science 10(4):573-90. doi: 10.1007/s13753-019-00227-z.

[13] Hasanah, Hasyim. 2017. "PEMAHAMAN KESEHATAN REPRODUKSI BAGI PEREMPUAN: Sebuah Strategi Mencegah Berbagai Resiko Masalah Reproduksi Remaja." Sawwa: Jurnal Studi Gender 11(2):229. doi: 10.21580/sa.v11i2.1456.

[14] Kang, Myounggu, Yeol Choi, Jeongseob Kim, Kwan Ok Lee, Sugie Lee, In Kwon Park, Jiyoung Park, and Ilwon Seo. 2020. "COVID-19 Impact on City and Region: What's next after Lockdown?" International Journal of Urban Sciences. doi: 10.1080/12265934.2020.1803107.

[15] Kayem, Gilles, Edouard Lecarpentier, Philippe Deruelle, Florence Bretelle, Elie Azria, Julie Blanc, Caroline Bohec, Marie Bornes, Pierre François Ceccaldi, Yasmine Chalet, Céline Chauleur, Anne Gael Cordier, Raoul Desbrière, Muriel Doret, Michel Dreyfus, Marine Driessen, Marion Fermaut, Denis Gallot, Charles Garabédian, Cyril Huissoud, Dominique Luton, Olivier Morel, Franck Perrotin, Olivier Picone, Patrick Rozenberg, Loïc Sentilhes, Jeremy Sroussi, Christophe Vayssière, Eric Verspyck, Alexandre J. Vivanti, Norbert Winer, Vivien Alessandrini, and Thomas Schmitz. 2020. "A Snapshot of the COVID-19 Pandemic among Pregnant Women in France." Journal of Gynecology Obstetrics and Human Reproduction 49(7):1-5. doi: 10.1016/j.jogoh.2020.101826.

[16] Komnas Perempuan. 2020. "Catatan Tahunan Kekerasan Terhadap Perempuan."

[17] Macauley, Kelly, dkk. 2018. "Prevalence and Predictors of Anxiety in Healthcare Professions Students." Science Direct, Health Professions Education 4((3)):176-85.

[18] McLaren, Helen Jaqueline, Karen Rosalind Wong, Kieu Nga Nguyen, and Komalee Nadeeka Damayanthi Mahamadachchi. 2020. "COVID-19 and Women's Triple Burden: Vignettes from Sri Lanka, Malaysia, Vietnam and Australia.” Social Sciences 
9(5). doi: 10.3390/SOCSCI9050087.

[19] Nurhadianti, Dini Diah. 2019. "COVID-19 Dan Perubahan Perilaku Menuju Adaptasi Kebiasaan Baru: Ditinjau Dari Perspektif Health Belief Model Theory." Fakultas Psikologi Universitas Persada Indonesia.

[20] Nurjasmi, Emi. n.d. "Situasi Pelayanan Kebidanan Pada Masa Pandemi Covid - 19 Dan Memasuki Era New-Normal." Ikatan Bidan Indonesia.

[21] Oskovi-Kaplan, Z. Asli, Gül Nihal Buyuk, A. Seval Ozgu-Erdinc, H. Levent Keskin, Alper Ozbas, and Ozlem Moraloglu Tekin. 2021. "The Effect of COVID-19 Pandemic and Social Restrictions on Depression Rates and Maternal Attachment in Immediate Postpartum Women: A Preliminary Study." Psychiatric Quarterly 92(2):675-82. doi: 10.1007/s11126-020-09843-1.

[22] Pope, Johanna, Ellinor K. Olander, Sara Leitao, Sarah Meaney, and Karen MatvienkoSikar. 2021. "Prenatal Stress, Health, and Health Behaviours during the COVID-19 Pandemic: An International Survey." Women and Birth (xxxx). doi: 10.1016/j.wombi.2021.03.007.

[23] Power, Kate. 2020. "The COVID-19 Pandemic Has Increased the Care Burden of Women and Families." Sustainability: Science, Practice, and Policy 16(1):67-73. doi: 10.1080/15487733.2020.1776561.

[24] Pradana, Anung Ahadi,. Casman, dan Nur'aini. 2020. "Pengaruh Kebijakan Social Distancing Pada Wabah COVID-19 Terhadap Kelompok Rentan Di Indonesia.” Jurnal Kebijakan Kesehatan Indonesia Vol. 09.

[25] Preis, Heidi, Brittain Mahaffey, Cassandra Heiselman, and Marci Lobel. 2020. "Vulnerability and Resilience to Pandemic-Related Stress among U.S. Women Pregnant at the Start of the COVID-19 Pandemic." Social Science and Medicine 266(September):113348. doi: 10.1016/j.socscimed.2020.113348.

[26] Reinissa, Arindita. Fitri Indrawati. 2017. "Persepsi Ibu Nifas Tentang Pelayanan Postnatal Care Dengan Kunjungan Ulang." Higeia Journal Of Public Health Research And Development Vol. 1((3)).

[27] Rotshenker-Olshinka, Keren, Alexander Volodarsky-Perel, Naama Steiner, Eryn Rubenfeld, and Michael H. Dahan. 2021. "COVID-19 Pandemic Effect on Early Pregnancy: Are Miscarriage Rates Altered, in Asymptomatic Women?" Archives of Gynecology and Obstetrics 303(3):839-45. doi: 10.1007/s00404-020-05848-0.

[28] Sarker, Mou Rani. 2021. "Labor Market and Unpaid Works Implications of COVID-19 for Bangladeshi Women.” Gender, Work and Organization 28(S2):597-604. doi: 10.1111/gwao.12587.

[29] Sulaeman, Kirana Mahdiah, and Fenny Rizka Salsabila. 2020. "Dampak COVID-19 Terhadap Kaum Perempuan: Perspektif Feminisme.” Jurnal Sentris 1(2):159-72. doi: 10.26593/sentris.v1i2.4283.159-172.

[30] Team, Victoria, and Lenore Manderson. 2020. "How COVID-19 Reveals Structures of Vulnerability." Medical Anthropology: Cross Cultural Studies in Health and Illness 39(8):671-74. doi: 10.1080/01459740.2020.1830281.

[31] Thibaut, Florence, and Patricia J. M. van Wijngaarden-Cremers. 2020. "Women's Mental Health in the Time of COVID-19 Pandemic." Frontiers in Global Women's Health 1(December):1-6. doi: 10.3389/fgwh.2020.588372.

[32] UN Women and Women Count. 2020. "Menilai Dampak Covid -19 Terhadap Gender Dan Pencapaian Tujuan Pembangunan Berkelanjutan Di Indonesia."

[33] Varney, H., Krebs, J.M., \& Gegor, C. L. 2001. Buku Saku Bidan Terjemahan. Jakarta: ECG. 